\title{
MALARIA AND NATURAL DISASTERS: EVIDENCE USING GMM APPROACH
}

\author{
Harpaljit Kaur* \\ Taylor's University \\ Muzafar Shah Habibullah \\ Universiti Putra Malaysia \\ Shalini Nagaratnam \\ Universiti Putra Malaysia
}

\begin{abstract}
Natural disasters not only disrupt accessibility to education, health care, food supplies and clean water, but causes outbreak of diseases. These issues deteriorate the health conditions among the victims of disasters and reduce human capital accumulation that adversely affects the economic development of the country. This paper examines the impact of total disasters and floods on malaria incidences using panel data over the period 2008 to 2014 for 79 countries. For robustness check, we use two measures on each of these natural disasters; the number of occurrences and number of people affected by these disasters. Employing the system Generalized Method of Moment (GMM) model, the findings show that the occurrences and the number of people affected by total disasters and flood, significantly increases cases of malaria. Income and education negatively impact the incidences of malaria whereas urbanization and deforestation increase the rates of malaria cases.
\end{abstract}

Keywords: Natural disaster; Malaria; GMM.

Received: 13 August 2018

Accepted: 20 May 2020

\section{INTRODUCTION}

Natural disasters have become one of the mounting risks faced by the world today due to the changes in the global climatic environment (Mach \& Mastrandrea, 2014; Mal, Singh, Huggel, \& Grover, 2018). It affects millions of people every year and the impact can be disastrous as it brings with them a host of various issues that include humanitarian, environmental, infrastructure and health problems. Many lives are lost and millions of people are made homeless due to the impact of the different types of disasters and its severity, leading to disruption in accessibility to education, health care, food supplies, clean water and outbreak of diseases. These issues deteriorate the health conditions among the victims of disasters, and continued disruption reduces human capital accumulation that adversely affects the economic development of the country. Natural disasters

\footnotetext{
* Corresponding author: School of Accounting and Finance, Faculty of Business and Law, Taylor's University, Selangor, Malaysia. Tel: (603) 56295662, Email: HarpaljitKaur.PritamSingh@taylors.edu.my
} 
have affected 6.11 billion people, killed 1.86 million people, and caused damages of USD 3.18 trillion from the period 1989 to 2018 (EM-DAT Database). The highest numbers of disasters within these 30 years was in the year 2000 with 526 natural disasters followed by the year 2002 where there were 505 disasters, as shown in Figure 1.

Figure 1: The Number of Natural Disasters for the period 1989-2018

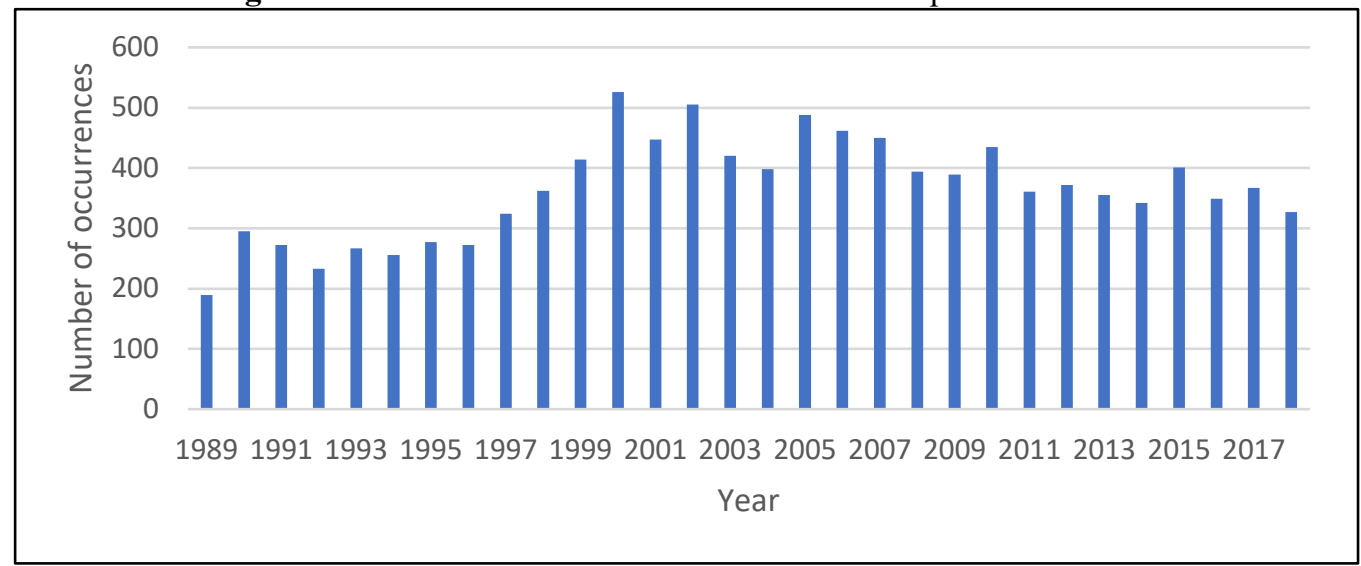

Source: EM-DAT Database

During this period, floods were the most frequent disaster, followed by storm, earthquake, and landslides (Table 1). In terms of number of deaths, earthquake top the list followed by storm, flood, and extreme temperature and in terms of people affected; the highest is floods, followed by drought, storm and earthquake. Storm, earthquake, floods, and droughts, in that order, caused the highest amount of damages. Floods affected almost 3.15 billion people between the years 1989 to 2018 and seem to be very frequent in regions that are undergoing large-scale rapid transformation towards urbanization. On the other hand, drought, which accounts for $4.79 \%$ of the disaster events, affected 1.7 billion people ( $28 \%$ of the overall number of people affected) during the same period despite early warnings being in place.

Table 1: Types of Natural Disasters from 1989 to 2018

\begin{tabular}{lcccc}
\hline \hline \multicolumn{1}{c}{ Disaster type } & $\begin{array}{c}\text { Number of } \\
\text { occurrences }\end{array}$ & Total deaths & $\begin{array}{c}\text { Total affected } \\
\text { (million) }\end{array}$ & $\begin{array}{c}\text { Total damage (USD } \\
\text { billion) }\end{array}$ \\
\hline Drought & 464 & 24532 & 1706.62 & 152.54 \\
Earthquake & 805 & 825284 & 141.29 & 744.95 \\
Extreme temperature & 508 & 172546 & 103.40 & 55.17 \\
Flood & 3970 & 199710 & 3151.82 & 737.11 \\
Landslide & 516 & 26077 & 6.74 & 8.17 \\
Mass movement & 28 & 1100 & 0.021 & 0.008 \\
Storm & 2924 & 412597 & 963.87 & 1374.31 \\
\hline \hline
\end{tabular}

Source: EM-DAT Database 
Natural disasters cause stagnant water and sewage, which affect the sanitation systems and increases mosquitoes breeding sites (Chan, 2017; Kouadio, Aljunid, Kamigaki, Hammad, \& Oshitani, 2012; Watson, Gayer, \& Connolly, 2007). More than 17\% of all the global infectious diseases are vector borne diseases which amounts to 700000 deaths per year (World Health Organisation [WHO], 2017) and among all this vector borne diseases, malaria alone causes about more than 400000 deaths worldwide yearly. According to WHO (2017) forty percent of the population worldwide live in intensified malaria risk areas. In addition, the number of malaria cases have increased from 211 million cases and 446000 deaths in the year 2015 to 231 million cases and 416000 deaths in 2017 (WHO, 2018). Malaria, a life-threatening disease caused by Plasmodium parasites, are transmitted exclusively to people through the bites of infected Anopheles mosquitoes (Githeko, Lindsay, Confalonieri, \& Patz, 2000) and any changes in the environmental conditions can trigger the activity and density of the population of the mosquitoes, thus affecting the incidence of malaria (Norris, 2004). Transmission rates of mosquito borne diseases increase with higher global temperatures and the geographical ranges of these diseases expands as more areas experience higher temperatures (Bueno-Mari \& Jimenez-Pevdro, 2013; Reiter, 2001; Sutherst, 2004). In addition, disasters contaminate water, air, and soil at the agricultural and chemical repositories (Patz, Grabow, \& Limaye, 2014) and causes overcrowding of the displacement areas (Ahmad, Ahmad, Ahmad, \& Ahmad, 2017), thus, increasing the probability of water-borne and vector-borne diseases (WHO, 2015).

Almost half of the world's population or about 3.2 billion people across 91 countries are at risk of malaria (WHO, 2017). Even though there has been a decrease of $18 \%$ in the incidence rate of malaria worldwide from 2010 to 2016 , a significant increase in malaria cases have been reported in America region between 2014 to 2016 whereas during the same period, South East region, Western Pacific region and African region experience a marginal rise in incidences (WHO, 2017). In light of the increased threat of natural disasters due to the intensification of global climate change, there is a need to better understand the association and the underlying dynamics of malaria outbreak in the aftermath of natural disasters.

\section{LITERATURE REVIEW}

There exists an increased risk of infectious diseases among the people affected in the aftermath of natural disasters (Chan et al., 2017; Ligon, 2006), especially among the developing countries. Malaria outbreaks increased the morbidity among children (Greenough, McGeehin, Bernard, Trtanj, Riad, \& Engelberg, 2001; de la Fuente \& Fuentes-Nieva, 2010; Shultz, Russell, \& Espinel, 2005), males (Li et al., 2007) and older people (Ding et al., 2014). Studies have found that natural disasters increase the transmission rates of mosquito borne diseases through higher global temperatures (Servadio, Rosenthal, Carlson \& Bauer, 2018; Reiter, 2001), drainage of large areas of wetland and swamps (Parmesan \& Martens, 2009), flooded rice fields (Wilder-Smith, 2005) and waterlogging (Ahmed et al., 2012). Collectively, these studies clearly indicate that there is a relationship between natural disasters and transmission of malaria rates.

Up to now, several studies have linked forest loss with infectious diseases. Significant forest loss to accommodate to agriculture, urbanization and to the growing global demand for food and natural resources (Stehman, Wickham, Wade, \& Smith, 2008; DeFries, Rudel, Uriarte, \& Hansen, 2010) have enhanced the risk of diseases like vector-borne diseases (Chaves \& Kitron, 2011; Laporta, de 
Prado, Kraenkel, Coutinho, \& Sallum, 2013; Colwell, Dantas-Torres, \& Otranto, 2011; Altizer, Ostfeld, Johnson, Kutz, \& Harvell, 2013) and water-borne diseases (Saravanan, Idenal, Saiyed, Saxena, \& Gerke, 2016).

Loss of forest increases the amount of stagnant water and sunlight, promoting breeding grounds for Anopheles mosquitoes, thus increasing mosquito's reproduction (Patz, Graczyk, Geller, \& Vittor, 2000; Vittor et al., 2009). There have been mixed findings on the relationship between deforestation and malaria cases. A number of authors have concluded that deforestation have a strong positive relationship with malaria transmission cases (Vittor et al., 2006; Tadei, Thatcher, Santos, Scarpassa, Rodrigues, \& Rafael, 1998; da Silva-Nunes et al., 2008; Vittor et al., 2009) whereas others found a negative relationship between these two variables (de Castro, Monte-Mór, Sawyer, \& Singer , 2006; Moutinho, Gil, Cruz, \& Ribolla, 2011). Other studies have strongly connected growing cases of malaria transmission with other forest related activities like agriculture and hunting (Valle, Clark, \& Zhao, 2011).

Some researchers have linked overcrowding with infectious disease outbreak. The increase in world population and globalization have increased mobility of people moving to the cities and creating rapid and unplanned rural-urban migration leading to overcrowding which substantially posed new challenges such as adequate supply of water, sanitation services and outbreak of water related diseases (WHO, 2015; Donner \& Rodriguez, 2011). The urban population is expected to be over 5 billion people in 2030 and the land allocated for urban landscapes is expected to be three times the levels in the year 2000 (Seto, Sánchez-Rodríguez, \& Fragkias, 2010). One of the effects of unplanned urbanization is slum dwellers who live in overcrowded, poorly built housing with insecure land tenure and are exposed to poor sanitation and less access to safe food and water, thus become more vulnerable to infectious diseases (Adagbada, Adesida, Nwaokorie, Niemogha, \& Coker, 2012; Bishwajit, Ide, \& Ghosh 2014). In addition, infectious diseases have shown lower economic growth (Acemoglu \& Johnson, 2007; Bleakley, 2007), lower educational outcomes (Barreca, 2010) and declining fertility (Lucas, 2010).

Past studies have shown that there exists a negative link between malaria cases and income per capita (Sachs \& Malaney, 2002; Alemu, Tsegaye, Golass, \& Abebe, 2011; Sychareun, Thomsen, $\&$ Faxelid, 2011). Alemu et al. (2011) found that prevalence of malaria was lesser among Ethiopian adults with monthly income more than 62.5 US dollars as compared to households with earnings less than 31.25 US dollars. Sychareun et al. (2011) found similar results in Lao PDR whereby majority of the pregnant women from low-income households tested positive for malaria. Education plays a vital role in preventing malaria cases as shown in studies by National Statistics Office [Malawi] and ORC Macro (2000) and Kaona, Siajunza, Manyando, Khondowe, and Ngoma (2000). National Statistics Office [Malawi] and ORC Macro (2000) concluded that more women with lower education level were tested positive for malaria s compared to women with higher education level. Due to poverty, women and girls had loss the opportunity to continue with education, thus dedicating their time to do house chores and relying on biodiversity product for generating income (Shandra, Shandra, \& London, 2008). However, due to loss of biodiversity and education opportunities, women and girls to be engaged in sexual activities to generate income to sustain their families, making them more vulnerable to infectious diseases (Appleton, 2000; Bechtel, 2010). 


\section{METHODOLOGY}

The main purpose of the present study is to provide empirical evidence of the impact of total natural disasters on infectious diseases. In the present study, we use the number of malaria cases to measure infectious diseases for a sample of 79 countries (shown in Appendix 1) from the period 2008 to 2014. Stagnant water due to the event of natural disasters, especially floods, creates breeding sites for mosquitoes. The determinants of infectious diseases are modelled as follows:

$$
\begin{aligned}
\text { LNMalaria }_{i t}= & \beta_{0}+\beta_{1} \text { LNND }_{i t}+\beta_{2} L N G D P P C_{i t}+\beta_{3} \text { LNUrban }_{i t} \\
& +\beta_{4} \text { LDForest }_{i t}+\beta_{5} L N E d u_{i t}+\varepsilon_{i t}
\end{aligned}
$$

where $L N M a l a r i a_{i t}$ represents malaria cases, $L N N D_{i t}$ denotes type of natural disaster (Total disasters and flood), $L N G D P P C_{i t}$ represent income per capita, $L N U r b a n_{i t}$ represent urbanization, $L D$ Forest $t_{i t}$ represent deforestation, $L N E d u_{i t}$ is secondary education and $\varepsilon_{i t}$ is the error term. For estimation, all variables were transformed into natural logarithm.

The data for malaria cases was obtained from World Health Organization database. The natural disaster data was obtained from Emergency Events Database (EM-DAT) maintained by the Center for Research on the Epidemiology of Disasters (CRED). EM-DAT defines a disaster as a natural situation or event, which overwhelms local capacity and/or necessitates a request for external assistance. For a disaster to be entered into the EM-DAT database, at least one of the following criteria must be met: (1) 10 or more people are reported killed; (2) 100 people are reported affected; (3) a state of emergency is declared; or (4) a call for international assistance is issued. In this study, we seek to study the impact of total disasters and flood, separately, on incidences of malaria. For each disaster, we employ two measures; the occurrences of natural disasters and the number of "people affected which includes the number of people injured, affected and made homeless" by these natural disasters.

The control variables used in this study are income per capita, urbanization, education and deforestation. Forest, being the most diverse and widespread ecosystems on earth, is vital to millions of people and almost 46000 to 58000 square miles of forest are lost every year, affecting livelihood of people and threatens a wide range of animals and plants (World Wildlife Fund [WWF], 2014). Deforestation represents the long-term or permanent loss of forest cover and implies transformation into another land use. Research on the impact of forest loss on infectious diseases shows that forest loss has positive impact on infectious diseases (Altizer et al., 2013; Chaves \& Kitron, 2011; Colwell et al., 2011; Laporta et al., 2013) and some studies have indicated a negative impact (Guerra, Snow, \& Hay, 2006). Other studies have strongly connected growing cases of malaria transmission with various forest related activities like agriculture and hunting (Gryseels et al., 2015; Valle et al., 2011). The data for deforestation was obtained from Global Forest Resource Assessments, Food and Agriculture Organization of the United Nations.

Urbanization due to human development activities are among the factors that have been indicated to increase the incidence of diseases such as dam development and irrigation projects to accommodate urbanization contributes to the increasing mosquitoes habitat (Dudgeon et al., 2006; Kibret, Lautze, McCartney, Wilson, \& Nhamo. 2015). Furthermore, increase in world population and globalization have created rapid and unplanned urbanization, having poorly built housing with insecure land tenure, poor sanitation and less access to safe food and water, thus become more 
vulnerable to infectious diseases (Adagbada et al., 2012; Bishwajit et al., 2014). Income and malaria cases are negatively linked and are coherent with Sachs and Malaney, (2002), Alemu et al. (2011) and Sychareun et al. (2011) whereas education plays a vital role in preventing malaria cases as shown in studies by National Statistics Office [Malawi] and ORC Macro (2000) and Kaona et al. (2000). The proxy used to represent education is the enrolment of secondary education whereas income is denoted by GDP per capita in constant 2010 USD. The data of urbanization, education and income were sourced from WDI database. All the control variables are expected to have a positive sign except for GDP per capita and education.

To achieve the objective of the present study on the impact of natural disasters on infectious diseases, we employ Generalized Method of Moments (GMM) proposed by Arellano-Bover (1995) and Blundell-Bond (1998). The equation is specified as:

$y_{i t}=\alpha y_{i t-1}+\beta x_{i t}^{\prime}+\delta N D_{i t}+\eta_{t}+\mu_{i}+\epsilon_{i t}$

where $y_{i t}$ represent the logarithm of malaria cases of country i and year t, $y_{i t-1}$ denotes the lagged malaria cases, $x_{i t}^{\prime}$ represents the set of explanatory variables determining infectious diseases, $N D_{i t}$ is the natural disaster measures, $\eta_{t}$ and $\mu_{i}$ denotes a time-specific effect and the county-specific effect, respectively and $\epsilon_{i t}$ is the error term. The GMM approach is suitable for panel data, which has shorter time dimension and larger country dimension. In addition, this method allows us to examine the effect of the past dependent variable on the present dependent variable (Roodman, 2009). GMM technique eliminates unobservable, individual fixed-effects by differencing, thus taking away the bias owing to the omission of country-specific technical efficiency. It also helps reduce the incidence of bias due to mis-measurement with the use of instrumental variables. In the current study, system GMM estimators are used for discussion purposes. System GMM, proposed by Arellano and Bover (1995) and Blundell and Bond (1998), reduce the potential biases and imprecision associated with the difference estimator. In addition, system GMM has more advantages as compared to difference GMM as it allows the use of more instruments that improves efficiency (Roodman, 2009) and is able to handle unbalanced data.

\section{RESULTS AND DISCUSSION}

The results of both one-step and two-step GMM results are presented in Table 2. The system GMM results fail to reject the null hypothesis that the over identifying restriction are valid. The p-value for $\mathrm{m}_{1}$ test shows the presence of first order serial correlation and the $\mathrm{p}$-value for $\mathrm{m}_{2}$ test indicates the absence of the second order autocorrelation. Therefore, the overall results shown in Table 2 suggest that the hypothesis of over identifying restrictions is valid and that zero-order autocorrelation cannot be rejected. This implies that the instruments used are valid and higher order autocorrelation is absent in the residuals. Hence, the results comply with the expected diagnostics. The coefficient of the lagged dependent variable is positive and statistically significant at $10 \%$ level. The implication is that the incidences of malaria are likely to increase when it has increased in the previous period. All the coefficients of natural disasters are positive, which concurs with most of the studies. In this present study, the two-step GMM results are reported and will be used for interpretation purposes. Two-step system GMM is preferred as it corrects the residuals for heteroscedasticity and it outperforms one-step system GMM (Arellano \& Bond, 1991). For each 
model, the Hansen J-statistics for over identification and the Arellano-Bond test for zero autocorrelation in first differenced errors are reported.

Table 2: Dynamic Panel Estimation Results: Number of Malaria cases and Natural Disaster

\begin{tabular}{|c|c|c|c|c|c|c|c|c|}
\hline \multirow[t]{2}{*}{ VARIABLES } & \multicolumn{4}{|c|}{ Number of occurrences } & \multicolumn{4}{|c|}{ Number of people affected } \\
\hline & $\begin{array}{c}\text { One-step } \\
\text { System }\end{array}$ & $\begin{array}{c}\text { Two-step } \\
\text { System }\end{array}$ & $\begin{array}{c}\text { One-step } \\
\text { System }\end{array}$ & $\begin{array}{c}\text { Two-step } \\
\text { System }\end{array}$ & $\begin{array}{c}\text { One-step } \\
\text { System }\end{array}$ & $\begin{array}{c}\text { Two-step } \\
\text { System }\end{array}$ & $\begin{array}{c}\text { One-step } \\
\text { System }\end{array}$ & $\begin{array}{c}\text { Two-step } \\
\text { System }\end{array}$ \\
\hline LNMalaria $_{(\mathrm{t}-1)}$ & $\begin{array}{c}0.615^{* * *} \\
(0.152)\end{array}$ & $\begin{array}{c}0.639 * * * \\
(0.196)\end{array}$ & $\begin{array}{c}0.675^{* * *} \\
(0.139)\end{array}$ & $\begin{array}{c}0.644 * * * \\
(0.153)\end{array}$ & $\begin{array}{c}0.536 * * * \\
(0.177)\end{array}$ & $\begin{array}{c}0.649 * * * \\
(0.191)\end{array}$ & $\begin{array}{c}0.565 * * * \\
(0.166)\end{array}$ & $\begin{array}{c}0.609^{* * *} \\
(0.159)\end{array}$ \\
\hline Total disasters ${ }_{t}$ & $\begin{array}{l}2.505^{* *} \\
(1.249)\end{array}$ & $\begin{array}{l}1.450^{* *} \\
(0.630)\end{array}$ & & & $\begin{array}{l}0.292^{* *} \\
(0.146)\end{array}$ & $\begin{array}{l}0.150^{*} \\
(0.078)\end{array}$ & & \\
\hline Flood $_{t}$ & & & $\begin{array}{c}1.671 * * * \\
(0.625)\end{array}$ & $\begin{array}{l}0.993 * \\
(0.577)\end{array}$ & & & $\begin{array}{c}0.263^{* *} \\
(0.112)\end{array}$ & $\begin{array}{l}0.161^{* *} \\
(0.065)\end{array}$ \\
\hline LNGDPPC & $\begin{array}{c}-0.903 * * \\
(0.412)\end{array}$ & $\begin{array}{c}-1.006^{* *} \\
(0.438)\end{array}$ & $\begin{array}{c}-1.422 * * * \\
(0.500)\end{array}$ & $\begin{array}{c}-1.513 * * * \\
(0.543)\end{array}$ & $\begin{array}{c}-1.407 * * \\
(0.552)\end{array}$ & $\begin{array}{c}-2.335 * * * \\
(0.673)\end{array}$ & $\begin{array}{c}-1.228 * * \\
(0.480)\end{array}$ & $\begin{array}{c}-1.328 * * \\
(0.526)\end{array}$ \\
\hline LNUrban & $\begin{array}{l}0.262^{*} \\
(0.145)\end{array}$ & $\begin{array}{l}0.262^{*} \\
(0.145)\end{array}$ & $\begin{array}{c}0.233 \\
(0.205)\end{array}$ & $\begin{array}{l}0.321^{*} \\
(0.171)\end{array}$ & $\begin{array}{l}0.359^{*} \\
(0.202)\end{array}$ & $\begin{array}{l}0.341^{*} \\
(0.206)\end{array}$ & $\begin{array}{c}0.264 \\
(0.200)\end{array}$ & $\begin{array}{l}0.339 * \\
(0.203)\end{array}$ \\
\hline LNDeforest & $\begin{array}{c}0.811 \\
(0.757)\end{array}$ & $\begin{array}{l}0.603 * \\
(0.312)\end{array}$ & $\begin{array}{c}0.131 \\
(0.462)\end{array}$ & $\begin{array}{c}0.041 \\
(0.217)\end{array}$ & $\begin{array}{c}1.572 \\
(1.170)\end{array}$ & $\begin{array}{c}1.113 \\
(0.725)\end{array}$ & $\begin{array}{l}1.356^{*} \\
(0.740)\end{array}$ & $\begin{array}{l}0.841^{*} \\
(0.432)\end{array}$ \\
\hline LNEdu & $\begin{array}{c}0.458 \\
(0.331)\end{array}$ & $\begin{array}{l}0.195 * \\
(0.101)\end{array}$ & $\begin{array}{c}0.439 \\
(0.276)\end{array}$ & $\begin{array}{c}0.094 \\
(0.073)\end{array}$ & $\begin{array}{c}-1.944 * * * \\
(0.715)\end{array}$ & $\begin{array}{c}-2.117^{* * *} \\
(0.599)\end{array}$ & $\begin{array}{c}-1.445^{* * *} \\
(0.468)\end{array}$ & $\begin{array}{c}-1.446 * * * \\
(0.517)\end{array}$ \\
\hline Constant & $\begin{array}{c}29.342 \\
(11.367)\end{array}$ & $\begin{array}{c}24.673^{* *} \\
(10.441)\end{array}$ & $\begin{array}{c}30.660 * * * \\
(8.852)\end{array}$ & $\begin{array}{c}23.743 * * \\
(9.530)\end{array}$ & $\begin{array}{l}37.731^{* *} \\
(15.279)\end{array}$ & $\begin{array}{l}23.534 * * \\
(-10.932)\end{array}$ & $\begin{array}{c}30.772 * * * \\
(11.360)\end{array}$ & $\begin{array}{c}26.749 * * \\
(12.131)\end{array}$ \\
\hline $\begin{array}{l}\text { Number of } \\
\text { Observations }\end{array}$ & 337 & 337 & 337 & 337 & 337 & 337 & 337 & 337 \\
\hline $\begin{array}{l}\text { Number of } \\
\text { Countries }\end{array}$ & 79 & 79 & 79 & 79 & 79 & 79 & 79 & 79 \\
\hline $\begin{array}{l}\text { Number of } \\
\text { Instruments }\end{array}$ & 44 & 48 & 44 & 48 & 44 & 48 & 44 & 48 \\
\hline $\mathrm{m}_{1}$ test & 0.011 & 0.050 & 0.025 & 0.065 & 0.005 & 0.049 & 0.016 & 0.052 \\
\hline $\mathrm{m}_{2}$ test & 0.896 & 0.987 & 0.987 & 0.831 & 0.883 & 0.590 & 0.764 & 0.906 \\
\hline $\begin{array}{l}\text { Hansen p- } \\
\text { value }\end{array}$ & 0.854 & 0.763 & 0.695 & 0.695 & 0.857 & 0.853 & 0.812 & 0.812 \\
\hline
\end{tabular}

Notes: 1. t-statistics are shown in parentheses. * $* *$ and $* * *$ denote significance at $10 \%, 5 \%$ and $1 \%$, respectively.

2. The values reported for Hansen test are the p-values. 3. The values reported for $m_{1}$ and $m_{2}$ tests are the p-values for the first and second order serial correlation.

We first consider the effect of number of natural disaster occurrences on malaria cases as shown in Table 2. The malaria incidences increase as a country experiences more events of total disasters and flood, significant at conventional levels (columns 2 to 5). It is interesting to note that the effects are relatively different for both the disasters. Specifically, the results of the two-step GMM approach suggest that when everything else is kept constant, one percent increase in total disaster and flood events respectively, leads to an increase in cases of malaria by $1.450 \%$ and $0.993 \%$. Furthermore, the malaria cases will increase as more people are affected by natural disasters 
(columns 6 to 9). A one percent increase in number of people affected by total disaster and flood increase the cases by $0.150 \%$ and $0.161 \%$, respectively.

The results above evidently support the hypothesis that different types of natural disasters increase the malaria cases and the effects differ across the two disasters. The results of this study confirm the view that natural disasters are positively associated infectious diseases of the 79 sampled countries, consistent with the findings of Shultz et al., 2005; de la Fuente and Fuentes-Nieva, 2010; Chaves and Kitron, 2011; Laporta et al., 2013 and Colwell et al., 2011. However, the effects differ substantially across disasters and different measures of natural disasters. The occurrences and the number of people affected by total disasters and flood, significantly increases cases of malaria. These findings are broadly in line with Shultz et al. (2005), Parmesan and Martens (2009) and de la Fuente and Fuentes-Nieva (2010). People who are affected by natural disasters have to stay at temporary shelters or outside their damages properties, increasing their contact with the mosquitoes, as there is minimal or no protection from mosquitoes. Furthermore, overflowed drainage and stagnant water due to disasters creates explosive growth of mosquitoes.

We next consider the effect of the control variables on the malaria cases. The GDP per capita is negative and significant for all, suggesting that income per capita affect the number of malaria cases. People with lower income are at greater risk of getting malaria due to lower access to health care, poor housing and low nutritional status. Education is negative and significant for flood total disasters when people are affected by natural disasters. Education increases the awareness of people on the disease and allows people to take proper steps in reducing the incidence and seeking for proper medical treatments if need arises (Bates et al., 2004; Dike, Onwujekwe, Ojukwu, Ikeme, Uzochukwu, \& Shu, 2006; Williams, Martina, Cumming, \& Hall, 2009). In addition, urbanization is positive and significant at least at $10 \%$ significance level in most specifications indicating that urbanization rises the rates of malaria cases. Increase in world population and globalization have created rapid and unplanned urbanization, having poorly built housing with insecure land tenure, poor sanitation and less access to safe food and water, thus become more vulnerable to infectious diseases (Adagbada et al., 2012; Bishwajit et al., 2014).

Deforestation increases malaria cases when more total disasters occur and when more people are affected during the events of flood. Our results are generally coherent with Chaves and Kitron (2011), Laporta et al. (2013), Colwell et al. (2011) and Altizer et al. (2013). There have been inconclusive findings on the relationship between deforestation and malaria cases. Vittor et al. (2006), Tadei et al. (1998), da Silva et al. (2008) and Vittor et al. (2009) concluded that deforestation have a strong positive relationship with malaria transmission cases whereas Moutinho et al. (2011) and de Castro et al. (2006) found a negative relationship between these two variables. Other studies have strongly connected growing cases of malaria transmission with other forest related activities like agriculture and hunting (Valle et al., 2011).

\section{CONCLUSION}

The results of this study confirm the view that natural disasters are positively associated with infectious diseases based on the 79 sampled countries, however, the effects differ substantially across disasters and different measures of natural disasters. The frequent occurrences of total disasters and flood events will lead to higher the incidences of malaria. It was also found that there 
is also a rise in the cases of malaria when total disaster and floods affect more people. Deforestation increases malaria cases when more total disasters occur and when more people are affected during the events of flood. In addition, increase in world population and globalization created rapid and unplanned urbanization making it more vulnerable to infectious diseases. Income and education negatively affect the number of malaria cases. Policy makers and government should create more awareness in schools by introducing health education especially in primary and secondary education. Educating adolescents about the causes and featuring ways of treating and preventing malaria infection should be made part of the curriculum in schools. In addition, policy makers should implement more sustainable forest management to decrease the severity of the risk of malaria.

\section{ACKNOWLEDGEMENT}

The authors extend our warmest appreciation to the Ministry of Higher Education Malaysia for the MyBrain sponsorship.

\section{REFERENCES}

Acemoglu, D., \& Johnson, S. (2007). Disease and development: The effect of life expectancy on economic growth. Journal of Political Economy, 115(6), 925-985.

Adagbada, A. O., Adesida, S. A., Nwaokorie, F. O., Niemogha, M.-T., \& Coker, A. O. (2012). Cholera Epidemiology in Nigeria: An overview. The Pan African Medical Journal, 12, 59. Retrieved from https://www.ncbi.nlm.nih.gov/pmc/articles/PMC3428179/

Ahmad, J., Ahmad, A., Ahmad, M. M., \& Ahmad, N. (2017). Mapping displaced populations with reference to social vulnerabilities for post-disaster public health management. Geospatial Health, 12(2), 325-334. doi: 10.4081/gh.2017.576

Ahmed, F., Rafii, M. Y., Ismail, M. R., Juraimi, A. S., Rahim, H. A., Asfaliza, R., \& Latif, M. A. (2013). Waterlogging tolerance of crops: breeding, mechanism of tolerance, molecular approaches, and future prospects. BioMed Research International, 2013, 1-10. doi: $10.1155 / 2013 / 963525$

Alemu, A., Tsegaye, W., Golassa, L., \& Abebe, G. (2011). Urban malaria and associated risk factors in Jimma town, south-west Ethiopia. Malaria Journal, 10(1), 173. doi: $10.1186 / 1475-2875-10-173$

Altizer, S., Ostfeld, R. S., Johnson, P. T., Kutz, S., \& Harvell, C. D. (2013). Climate change and infectious diseases: From evidence to a predictive framework. Science, 341(6145), 514519.

Appleton, S. (2000). Education and health at the household level in sub-Saharan Africa (No. 33). Center for International Development at Harvard University.

Arellano, M., \& Bond, S. (1991). Some tests of specification for panel data: Monte Carlo evidence and an application to employment equations. The Review of Economic Studies, 58(2), 277.

Arellano, M., \& Bover, O. (1995). Another look at the instrumental variable estimation of errorcomponents models. Journal of Econometrics, 68(1), 29-51.

Barreca, A. I. (2010). The long-term economic impact of in utero and postnatal exposure to malaria. Journal of Human Resources, 45(4), 865-892. 
Bates, I., Fenton, C., Gruber, J., Lalloo, D., Lara, A. M., Squire, S. B., \& Tolhurst, R. (2004). Vulnerability to malaria, tuberculosis, and HIV/AIDS infection and disease. Part 1: determinants operating at individual and household level. The Lancet Infectious Diseases, 4(5), 267-277.

Bechtel, J. (2010). Gender, poverty and the conservation of biodiversity: A review of issues and opportunities. MacArthur Foundation Conservation White Paper Series. https://www.macfound.org/media/files/CSD_GENDER_WHITE_PAPER.pdf

Bishwajit, G., Ide, S., \& Ghosh, S. (2014). Social Determinants of Infectious Diseases in South Asia. International Scholarly Research Notices, 2014, 1-10. doi: 10.1155/2014/135243

Bleakley, H. (2007). Disease and development: evidence from hookworm eradication in the American South. The Quarterly Journal of Economics, 122(1), 73-117.

Blundell, R., \& Bond, S. (1998). Initial conditions and moment restrictions in dynamic panel data models. Journal of Econometrics, 87(1), 115-143.

Bueno-Marí, R., \& Jiménez-Peydró, R. (2013). Global change and human vulnerability to vectorborne diseases. Front Physiol, 4(158), 10-3389.

Chan, C. W., Iata, H., Yaviong, J., Kalkoa, M., Yamar, S., Taleo, G., \& Dancause, K. N. (2017). Surveillance for malaria outbreak on malaria-eliminating islands in Tafea Province, Vanuatu after Tropical Cyclone Pam in 2015. Epidemiology \& Infection, 145(1), 41-45.

Chan, E. Y. Y. (2017). Public Health Humanitarian Responses to Natural Disasters. Taylor \& Francis.

Chaves, L. F., \& Kitron, U. D. (2011). Weather variability impacts on oviposition dynamics of the southern house mosquito at intermediate time scales. Bulletin of Entomological Research, 101(6), 633-641.

Centre for Research on the Epidemiology of Disaster (CRED.) (2000). EMDAT. The OFDA/ CRED international disaster database. Brussels: Universite Catholicque de Louvain. Retrieved from www.emdat.be

Colwell, D. D., Dantas-Torres, F., \& Otranto, D. (2011). Vector-borne parasitic zoonoses: Emerging scenarios and new perspectives. Veterinary Parasitology, 182(1), 14-21.

da Silva-Nunes, M., Codeço, C. T., Malafronte, R. S., Da Silva, N. S., Juncansen, C., Muniz, P. T., \& Ferreira, M. U. (2008). Malaria on the Amazonian frontier: Transmission dynamics, risk factors, spatial distribution, and prospects for control. The American Journal of Tropical Medicine and Hygiene, 79(4), 624-635.

de Castro, M. C., Monte-Mór, R. L., Sawyer, D. O., \& Singer, B. H. (2006). Malaria risk on the Amazon frontier. Proceedings of the National Academy of Sciences of the United States of America, 103(7), 2452-2457.

de la Fuente, A., \& Fuentes-Nieva, R. (2010). The impact of natural shocks on children morbidity in rural Mexico. In Risk, Shocks, and Human Development (pp. 103-127). Palgrave Macmillan, London.

DeFries, R. S., Rudel, T., Uriarte, M., \& Hansen, M. (2010). Deforestation driven by urban population growth and agricultural trade in the twenty-first century. Nature Geoscience, 3(3), 178.

Dike, N., Onwujekwe, O., Ojukwu, J., Ikeme, A., Uzochukwu, B., \& Shu, E. (2006). Influence of education and knowledge on perceptions and practices to control malaria in Southeast Nigeria. Social Science \& Medicine, 63(1), 103-106.

Ding, G., Gao, L., Li, X., Zhou, M., Liu, Q., Ren, H., \& Jiang, B. (2014). A mixed method to evaluate burden of malaria due to flooding and waterlogging in Mengcheng County, China: A case study. PloS ONE, 9(5). doi:10.1371/journal.pone.0097520 
Donner, W., \& Rodríguez, H. (2011). Disaster risk and vulnerability: The role and impact of population and society. Population Reference Bureau: Washington, DC, USA.

Dudgeon, D., Arthington, A. H., Gessner, M. O., Kawabata, Z. I., Knowler, D. J., Lévêque, C., \& Sullivan, C. A. (2006). Freshwater biodiversity: Importance, threats, status, and conservation challenges. Biological Reviews, 81(2), 163-182.

Githeko, A. K., Lindsay, S. W., Confalonieri, U. E., \& Patz, J. A. (2000). Climate change and vector-borne diseases: A regional analysis. Bulletin of the World Health Organization, 78(9), 1136-1147.

Greenough, G., McGeehin, M., Bernard, S. M., Trtanj, J., Riad, J., \& Engelberg, D. (2001). The potential impacts of climate variability and change on health impacts of extreme weather events in the United States. Environmental Health Perspectives, 109 (Suppl 2), 191-198. doi: 10.1289/ehp.109-1240666

Gryseels, C., Durnez, L., Gerrets, R., Uk, S., Suon, S., Set, S., \& Coosemans, M. (2015). Reimagining malaria: Heterogeneity of human and mosquito behaviour in relation to residual malaria transmission in Cambodia. Malaria Journal, 14(1). doi: 10.1186/s12936-015-0689-0

Guerra, C. A., Snow, R. W., \& Hay, S. I. (2006). A global assessment of closed forests, deforestation and malaria risk. Annals of Tropical Medicine and Parasitology, 100(3), 189.

Kaona, F., Siajunza, M. T., Manyando, C., Khondowe, S., \& Ngoma, G. K. (2000). Utilisation of malarial drugs at a household level: Results from a KAP study in Choma, southern province and Mporokoso, northern province of Zambia. The Central African Journal of Medicine, 46(10), 268-270

Kibret, S., Lautze, J., McCartney, M., Wilson, G. G., \& Nhamo, L. (2015). Malaria impact of large dams in sub-Saharan Africa: Maps, estimates and predictions. Malaria Journal, 14(1). doi: 10.1186/s12936-015-0873-2

Kouadio, I. K., Aljunid, S., Kamigaki, T., Hammad, K., \& Oshitani, H. (2012). Infectious diseases following natural disasters: Prevention and control measures. Expert Review of AntiInfective Therapy, 10(1), 95-104.

Laporta, G. Z., de Prado, P. I. K. L., Kraenkel, R. A., Coutinho, R. M., \& Sallum, M. A. M. (2013). Biodiversity can help prevent malaria outbreaks in tropical forests. PLoS Neglected Tropical Diseases, 7(3), Article e2139. doi: 10.1371/journal.pntd.0002139

Li, X., Tan, H., Li, S., Zhou, J., Liu, A., Yang, T., \& Sun, Z. (2007). Years of potential life lost in residents affected by floods in Hunan, China. Transactions of the Royal Society of Tropical Medicine and Hygiene, 101(3), 299-304.

Ligon, B. L. (2006). Infectious diseases that pose specific challenges after natural disasters: A review. Seminars in Pediatric Infectious Diseases, 17(1), 36-45. doi: 10.1053/j.spid.2006.01.002

Lucas, A. M. (2010). Malaria eradication and educational attainment: Evidence from Paraguay and Sri Lanka. American Economic Journal: Applied Economics, 2(2), 46-71.

Mach, K., \& Mastrandrea, M. (2014). Climate change 2014: Impacts, adaptation, and vulnerability (Vol. 1). C. B. Field, \& V. R. Barros (Eds.). Cambridge and New York: Cambridge University Press.

Mal S., Singh R.B., Huggel C., Grover A. (2018) Introducing linkages between climate change, extreme events, and disaster risk reduction. In S. Mal, R. Singh \& C. Huggel (Eds.). Climate Change, Extreme Events and Disaster Risk Reduction. Sustainable Development Goals Series (pp. 1-14). Springer, Cham. doi: 10.1007/978-3-319-56469-2_1 
Moutinho, P. R., Gil, L. H., Cruz, R. B., \& Ribolla, P. E. (2011). Population dynamics, structure and behavior of Anopheles darlingi in a rural settlement in the Amazon rainforest of Acre, Brazil. Malaria Journal, 10(1), 174. doi: 10.1186/1475-2875-10-174

National Statistics Office [Malawi] and ORC Macro (2000). Malawi demographic and health survey. Zomba, Malawi and Calverton, Maryland, USA. Retrieved from: https://hsprogram.com/pubs/pdf/FR123/FR123.pdf

Norris, D. E. (2004). Mosquito-borne diseases as a consequence of land use change. EcoHealth, 1(1), 19-24.

Parmesan, C., \& Martens, P. (2009). Climate change, wildlife, and human health. In O.E. Sala, L.A. Meyerson, \& C.Parmesan, Biodiversity Change and Human Health: From Ecosystem Services to Spread of Disease (pp. 245-266). Washington DC: Island Press.

Patz, J. A., Graczyk, T. K., Geller, N., \& Vittor, A. Y. (2000). Effects of environmental change on emerging parasitic diseases. International Journal for Parasitology, 30(12-13), 1395 1405. doi: 10.1016/s0020-7519(00)00141-7

Patz, J. A., Grabow, M. L., \& Limaye, V. S. (2014). When it rains, it pours: Future climate extremes and health. Annals of Global Health, 80(4), 332-344.

Reiter, P. (2001). Climate change and mosquito-borne disease. Environmental Health Perspectives, 109(Suppl 1), 141-161. doi: 10.1289/ehp.01109s1141

Roodman, D. (2009). How to do xtabond2: An introduction to difference and system GMM in Stata. The Stata Journal, 9(1), 86-136.

Sachs, J., \& Malaney, P. (2002). The economic and social burden of malaria. Nature, 415(6872), 680-685. doi: 10.1038/415680a

Saravanan, V. S., Ayessa Idenal, M., Saiyed, S., Saxena, D., \& Gerke, S. (2016). Urbanization and human health in urban India: Institutional analysis of water-borne diseases in Ahmedabad. Health Policy and Planning, 31(8), 1089-1099.

Servadio, J. L., Rosenthal, S. R., Carlson, L., \& Bauer, C. (2018). Climate patterns and mosquitoborne disease outbreaks in South and Southeast Asia. Journal of Infection and Public Health, 11(4), 566-571.

Seto, K. C., Sánchez-Rodríguez, R., \& Fragkias, M. (2010). The new geography of contemporary urbanization and the environment. Annual Review of Environment and Resources, 35(1), 167-194. doi: 10.1146/annurev-environ-100809-125336

Shandra, J. M., Shandra, C. L., \& London, B. (2008). Women, non-governmental organizations, and deforestation: A cross-national study. Population and Environment, 30(1-2), 48-72.

Shultz, J. M., Russell, J., \& Espinel, Z. (2005). Epidemiology of tropical cyclones: The dynamics of disaster, disease, and development. Epidemiologic Reviews, 27(1), 21-35.

Stehman, S. V., Wickham, J. D., Wade, T. G., \& Smith, J. H. (2008). Designing a multi-objective, multi-support accuracy assessment of the 2001 National Land Cover Data (NLCD 2001) of the conterminous United States. Photogrammetric Engineering \& Remote Sensing, 74(12), 1561-1571.

Sutherst, R. W. (2004). Global change and human vulnerability to vector-borne diseases. Clinical Microbiology Reviews, 17(1), 136-173.

Sychareun, V., Thomsen, S., \& Faxelid, E. (2011). Concurrent multiple health risk behaviors among adolescents in Luangnamtha province, Lao PDR. BMC Public Health, 11(1). doi: 10.1186/1471-2458-11-36

Tadei, W. P., Thatcher, B. D., Santos, J. M., Scarpassa, V. M., Rodrigues, I. B., \& Rafael, M. S. (1998). Ecologic observations on anopheline vectors of malaria in the Brazilian Amazon. The American Journal of Tropical Medicine and Hygiene, 59(2), 325-335. 
Valle, D., Clark, J. S., \& Zhao, K. (2011). Enhanced understanding of infectious diseases by fusing multiple datasets: A case study on malaria in the Western Brazilian Amazon region. PLoS ONE, 6(11), e27462. doi.org/10.1371/journal.pone.0027462

Vittor, A. Y., Gilman, R. H., Tielsch, J., Glass, G., Shields, T. I. M., Lozano, W. S., \& Patz, J. A. (2006). The effect of deforestation on the human-biting rate of Anopheles darlingi, the primary vector of falciparum malaria in the Peruvian Amazon. The American Journal of Tropical Medicine and Hygiene, 74(1), 3-11.

Vittor, A. Y., Pan, W., Gilman, R. H., Tielsch, J., Glass, G., Shields, T., \& Patz, J. A. (2009). Linking deforestation to malaria in the Amazon: Characterization of the breeding habitat of the principal malaria vector, Anopheles darlingi. The American Journal of Tropical Medicine and Hygiene, 81(1), 5-12.

Watson, J. T., Gayer, M., \& Connolly, M. A. (2007). Epidemics after natural disasters. Emerging Infectious Diseases, 13(1), 1-5. doi: 10.3201/eid1301.060779

Wilder-Smith, A. (2005). Tsunami in South Asia: what is the risk of post-disaster infectious disease outbreaks? Annals-Academy of Medicine Singapore, 34(10), 625-631.

Williams, P. C., Martina, A., Cumming, R. G., \& Hall, J. (2009). Malaria prevention in SubSaharan Africa: A field study in rural Uganda. Journal of Community Health, 34(4), 288294. doi: 10.1007/s10900-009-9151-y.

World Health Organization (2015). World health statistics 2015. Retrieved from: https://apps.who.int/iris/bitstream/handle/10665/170250/9789240694439_eng.pdf;jsessi onid $=$ C0911DB934B5029736A29772498B5526? sequence $=1$

World Health Organization (2017). World malaria report 2017. Retrieved from: https://apps.who.int/iris/bitstream/handle/10665/259492/9789241565523eng.pdf? sequence $=1$

World Health Organization (2018). World malaria report 2018. Retrieved from: https://apps.who.int/iris/bitstream/handle/10665/275867/9789241565653-eng.pdf

World Wildlife Fund (2014). Pacific annual report. Retrieved from: https://d3bzkjkd62gi12.cloudfront.net/downloads/annual_report_2014_final_printing.pd $\mathrm{f}$ 
Appendix 1: List of the 79 countries used in the study

\begin{tabular}{|c|c|c|c|c|}
\hline Afghanistan & Cameroon & Guatemala & Mauritania & Senegal \\
\hline Algeria & Chad & Guinea & Mexico & Sierra Leone \\
\hline Angola & China & Guyana & Mozambique & $\begin{array}{l}\text { Solomon } \\
\text { Islands }\end{array}$ \\
\hline Argentina & Colombia & Honduras & Namibia & South Africa \\
\hline Azerbaijan & Comoros & India & Nepal & Sri Lanka \\
\hline Bangladesh & Congo & Indonesia & Nicaragua & Sudan \\
\hline Belize & Congo Dem & Iran & Niger & Tajikistan \\
\hline Benin & Costa Rica & Jamaica & Nigeria & Tanzania \\
\hline Bhutan & Côte d'Ivoire & Kenya & Pakistan & Thailand \\
\hline Bolivia & Dominican Rep & Korea & Panama & Togo \\
\hline Botswana & Ecuador & Lao & Papua New Guinea & Uganda \\
\hline Brazil & El Salvador & Liberia & Paraguay & Vanuatu \\
\hline Burkina Faso & Eritrea & Madagascar & Peru & Venezuela \\
\hline Burundi & Ethiopia & Malawi & Philippines & Vietnam \\
\hline Cabo Verde & Gambia & Malaysia & Rwanda & Zimbabwe \\
\hline Cambodia & Ghana & Mali & Saudi Arabia & \\
\hline
\end{tabular}

